University of South Carolina

Scholar Commons

6-1992

\title{
Ideology, Status, and the Differential Success of Direct Parties Before the Supreme Court
}

\author{
Reginald S. Sheehan \\ University of North Texas \\ William Mishler \\ University of South Carolina - Columbia \\ Donald R. Songer \\ University of South Carolina - Columbia, dsonger@sc.edu
}

Follow this and additional works at: https://scholarcommons.sc.edu/poli_facpub

Part of the Political Science Commons

\author{
Publication Info \\ Published in American Political Science Review, Volume 86, Issue 2, 1992, pages 464-471. \\ http://journals.cambridge.org/action/displayJournal?jid=PSR \\ (C) 1992 by Cambridge University Press
}

This Article is brought to you by the Political Science, Department of at Scholar Commons. It has been accepted for inclusion in Faculty Publications by an authorized administrator of Scholar Commons. For more information, please contactdigres@mailbox.sc.edu. 


\title{
IDEOLOGY, STATUS, AND THE DIFFERENTIAL SUCCESS OF DIRECT PARTIES BEFORE THE SUPREME COURT
}

\author{
REGINALD S. SHEEHAN University of North Texas \\ WILLIAM MISHLER and DONALD R. SONGER University of South Carolina
}

\begin{abstract}
A substantial literature on lower federal courts and state courts suggests that the "haves" usually come out ahead in litigation because they possess superior resources for it and they reap advantages from their repeat player status. We investigate the success of 10 categories of litigants before the Warren, Burger, and Rehnquist Courts to determine whether the resources or experience of litigants has effects on Supreme Court outcomes paralleling those found in the courts below. While different categories of litigants are found to have very different rates of success, those differences do not consistently favor litigants with greater resources. A time series analysis of the success of different categories of litigants over the 36 years studied suggests that the changing ideological complexion of the Court has a greater impact on the success of litigants than differences among litigants in resources and experience.
\end{abstract}

$\mathbf{W}$ examine the impact of litigant status and the changing ideology of the U.S. Supreme Court on differences in the success rates of direct parties before the Court. Simply, we seek to explain why some categories of litigants win more frequently than others when appearing before the Court. Previous explanations have attributed differential success rates in lower federal courts to, inter alia, disparities between litigants of different status in judicial experience and resources. We argue, however, that differential success rates in Supreme Court decisions have more to do with the ideological composition of the Court and the Court's receptivity to the different types of legal claims made by litigants of different status.

Previous research indicates that the status of litigants before American courts has substantial influence on judicial outcomes. Higher-status parties enjoy significant advantages in appellate courts and usually win. This has been demonstrated in the U.S. courts of appeals (Sheehan and Songer 1989) and, to a lesser degree, in state supreme courts (Wheeler et al. 1987). Curiously, the impact of litigant status on U.S. Supreme Court decisions has not been widely studied.

Among other arguments frequently advanced to explain status differentials in litigant success rates are that higher-status litigants typically possess superior resources or greater litigation experience (or both). Galanter (1974), for example, cites the advantage that corporations and especially governments enjoy as "repeat players" in comparison to less-experienced single-shot litigants. Repeat players are presumably better able to "play for the rules" in the legal process. They can settle cases likely to be lost in the courts and appeal cases they have the best chance of winningand thus maximize their success rates.

In contrast, Sheehan and Songer (1989) stress the importance of resource differentials. They observe that even among single-shot litigants, the poor lose more frequently than wealthier individuals. Litigation, of course, is expensive. Litigants with superior resources can arguably retain better legal counsel, undertake more extensive research, and otherwise invest more in case preparation.

Another possibility, largely neglected in the literature, is that status differences in success rates reflect not only the relative resources and experience of litigants but also the values, ideological preferences, and prejudices of the Court. Numerous studies (Rohde and Spaeth 1976; Segal and Cover 1989; Tate 1981) document the effects that the political values of judges have on judicial decisions. Although no one to our knowledge has linked these values to litigant status, the connection is easily made in theory. Litigant status is related to the types of cases brought before the Court and to the positions taken by the parties. Cases brought by minorities, the poor, and individuals against businesses or government frequently emphasize claims of individual rights and liberties. Thus, they are likely to appeal to liberal values and to enjoy greater success in courts with liberal majorities. Conversely, cases brought by businesses against governments more typically seek regulatory relief, appealing to conservative values.

Our contention is that ideology is likely to be especially salient in cases before the U.S. Supreme Court. One reason is that litigant resource and experience differentials are likely to diminish both in size and importance at higher levels of the judicial system. Litigants whose cases have survived the gauntlet of the appeals process have proven they possess both considerable stamina and substantial resources. They also have acquired significant experience in the process. Assuming that status differences bear as much on decisions to grant certiorari as on decisions on merit, cases between litigants with the largest resource and experience differentials are unlikely to make it onto the Court's docket in the first place. Moreover, a case raising questions important enough 


\section{TABLE 1}

Net Advantage of Parties, 1953-88 (\%)

\begin{tabular}{|c|c|c|c|c|}
\hline $\begin{array}{l}\text { TYPE OF } \\
\text { PARTY }^{a}\end{array}$ & $\begin{array}{c}\text { OVERALL } \\
\text { SUCCESS RATE } \\
(1)\end{array}$ & $\begin{array}{c}\text { SUCCESS } \\
\text { RATE AS } \\
\text { RESPONDENT } \\
(2)\end{array}$ & $\begin{array}{c}\text { APPELLANT'S } \\
\text { OPPONENTS } \\
\text { SUCCESS RATE } \\
(3)\end{array}$ & $\begin{array}{c}\text { NET } \\
\text { ADVANTAGE }^{b} \\
(4)\end{array}$ \\
\hline Poor individual & 31.2 & 38.5 & 70.5 & -32.0 \\
\hline Minorities & 55.6 & 44.3 & 34.9 & 9.4 \\
\hline Individual & 42.9 & 35.2 & 52.6 & -17.4 \\
\hline Unions & 53.9 & 39.0 & 36.4 & 2.6 \\
\hline Small business & 42.7 & 29.2 & 46.9 & -17.7 \\
\hline Business & 44.3 & 36.0 & 47.9 & -11.9 \\
\hline Corporations & 38.6 & 29.3 & 48.6 & -19.3 \\
\hline Local govt & 45.8 & 43.1 & 49.4 & -6.3 \\
\hline State govt & 54.1 & 51.0 & 39.8 & 11.2 \\
\hline Federal govt & 67.3 & 59.1 & 23.2 & 35.9 \\
\hline
\end{tabular}

to be granted certiorari is likely to have sufficient cachet to attract quality counsel willing to argue the case for the visibility and prestige the case might bring. Parties to such cases can also frequently supplement their resources with contributions from concerned individuals and (especially) interest groups.

A second reason for hypothesizing that ideology will have a greater impact on the success of direct parties before the Supreme Court is our belief that ideological considerations are likely to be more sharply defined in cases reaching the Supreme Court. Again, because the Court controls its docket, it can select cases where peripheral issues are minimized and issues of principle predominate. Although there are exceptions, lower-level courts generally have less docket control and confront more cases where philosophical issues are obscured by other considerations.

\section{DATA AND MEASURES}

Data on the differential success rates of direct parties before the Supreme Court are available from the U.S. Supreme Court data base. The data base includes all cases decided with opinion by the Supreme Court between 1953 and 1988. Parties to these cases are identified by the labels given them in the Court's judgment or opinion. The detailed listing of parties in the data have been reduced to 10 categories: poor individuals, minority group individuals, other individuals, unions, small businesses, corporations, other businesses, local governments, state governments and the federal government. ${ }^{1}$

Since the Supreme Court data base is constructed from the written opinions of the Court, it does not provide direct measures of the financial resources or previous litigation experiences of litigants. To circumvent this problem we have adopted a strategy suggested by Wheeler and his colleagues (1987), ranking the 10 categories of litigants from strongest to weakest based on estimates of their financial resources and likely experience as repeat players in litigation. Although using status as a proxy for resources and experience precludes an assessment of the independent effects of resources versus experience, it does permit assessment of their combined effects vis-à-vis ideology.

To measure the changing ideological predisposition of the Supreme Court across the 36 years encompassed by this study, we use the ideology scores developed by Segal and Cover (1989) for individual justices. ${ }^{2}$ To create a composite measure of the ideology of the Court we sum Segal and Cover's individual ideology scores across the nine justices who comprise the Court in any year.

\section{RESULTS}

Table 1 reports the success rates of the 10 categories of litigants in cases decided by the Supreme Court during the years 1953-88. As expected, success rates vary widely across the several categories of litigants, ranging from $67 \%$ for the federal government to only $31 \%$ for poor individuals. However, the overall success rates of litigants can be misleading. Because the Supreme Court is well known for its tendency to reverse decisions from below, ${ }^{3}$ litigants whose cases are accepted on appeal are more likely to win than those who appear as respondents. To compensate for this, Table 1 also reports the net advantage of each class of litigant. This measure controls for appellant status by focusing upon the success rate of litigants in cases in which they are respondents and subtracting the success rate of their opponents in cases in which the opponents are respondents. ${ }^{4}$

If the resources and experience hypotheses are correct, we would expect the net advantage of the 10 litigant groups to vary directly with their status rankings. In fact, the relationship is quite weak. The federal and state governments enjoy significant advantages over other litigants, but so do minorities. 
Individuals, especially the poor, are severely disadvantaged before the Court; but so are corporations and small businesses.

The overall net advantage of a category of litigants can be misleading, because the nature of the cases in which they typically are involved may bring them into conflict disproportionately with stronger or weaker opponents. To control for this possibility, we calculated the net advantage of each category of litigants against each of the other nine categories of litigants in our analysis. The results reinforce our observations both of the extreme variation in success rates among parties and of the limited impact of status differences (resources and experience) on success.

Predictably, during the 36 years spanned by our analysis, the federal government enjoyed very large net advantages against all other parties. But the federal government is the only party that consistently dominated lower-status parties. In Table 2, the party assumed to have superior resources and experience had a net advantage in 20 of the 29 comparisons $(69 \%)$ for which sufficient cases are available. However, in 5 of those 20 cases, the advantage of the stronger party was negligible (i.e., five percentage points or less). Thus, the party presumed to be stronger enjoyed a clear-cut advantage in only 15 of 29 comparisons - just about what would be expected by chance if we knew nothing about the relative status of competing parties.

A different perspective on the resources argument is provided by examining the success rates of litigants over time. If resources and experience are determining factors in Supreme Court decisions, we would expect success rates to be relatively stable over time, since the relative resources and judicial experience of parties probably have not changed much over the years. In contrast, the ideological composition of the Court has changed dramatically. Thus, if ideology is a determining factor we would expect the success rates of different status litigants to vary significantly.

Table 3 displays the success rates for various combinations of litigants ${ }^{5}$ across three periods corresponding roughly with the Warren Court (1953-70), the early Burger Court (1971-80) and the later Burger and Rehnquist Courts (1981-88). ${ }^{6}$ Consistent with the ideology hypothesis and contrary to the resource hypothesis, the relative success rates of parties before the Supreme Court vary considerably. Predictably, individual litigants have suffered most from the growing conservatism of the Court, their success rates falling in relation to all other categories of litigants. ${ }^{7}$ The pattern among other pairs of litigants is more complex. Businesses have fared better against the federal government but worse against state and local governments. State governments fared better against the federal government during the early Burger years but much worse during the Rehnquist years. Although the reason for this is not immediately apparent, an explanation is offered in a subsequent section.

\section{TABLE 2}

Net Advantage for Different Combinations of Parties, 1953-1988

COMBINATIONS OF PARTIES

NET ADVANTAGE BY \%

Poor individuals vs.

Federal government

State government

Federal government, 52.4

Minorities vs.

Federal government

State government

Local government

Businesses (incl.

corp. \& sm.)

Poor individuals, 1.8

Individuals vs.

Federal government

State government

Local government

Businesses

Corporations

Unions

Unions vs.

Federal government

Businesses

Corporations

Small businesses vs.

Federal government

State government

Businesses

Corporations

Businesses vs.

Federal government

State government

Local government

Corporations

Federal government, 24.6

Minorities, 12.2

Minorities, 24.7

Minorities, 15.7

Federal government, 33.0

State government, 17.6

Local government, 5.4

Businesses, 2.1

Individuals, 17.1

Unions, 10.6

Federal government, 22.9

Unions, 30.7

Corporations, 16.7

Federal government, 21.3 State government, 23.1

Businesses, 50.0

Corporations, 5.7

Federal government, 43.8

State government, .9

Local government, 5.7

Businesses, 20.4

Corporations vs.

Federal government

State government

Local government

Federal government, 50.1

State government, 28.6

Corporations, 32.1

Local government vs.

Federal government

State government

Federal government, 16.2

Local government, 15.0

State government vs.

Federal government

Federal government, 30.3

\section{MULTIVARIATE MODELS}

So far, examination of the resource and ideology hypotheses has been limited to comparisons of success rates across different combinations of litigants over time. Although illuminating broad patterns, these comparisons do not provide systematic estimates of the relative effects of either status or ideology. To obtain such estimates, we report logistic regressions in Table 4 for all Supreme Court decisions between 1953 and 1988 that involve some combination of our four aggregate litigant groups (i.e., individuals, businesses, state and local governments, and 


\section{TABLE 3}

Success of Party Combinations over Time, 1953-88 (\%)

\begin{tabular}{|c|c|c|c|}
\hline $\begin{array}{c}\text { TYPE OF } \\
\text { PARTY }\end{array}$ & $1953-70$ & $1971-80$ & $1981-88$ \\
\hline $\begin{array}{l}\text { Individual }^{a} \text { vs. } \\
\text { Business }^{b} \\
\text { State and local } \\
\text { Federal }\end{array}$ & $\begin{array}{l}75.3(174) \\
65.6(518) \\
52.5(503)\end{array}$ & $\begin{array}{l}48.6(138) \\
40.5(870) \\
28.0(414)\end{array}$ & $\begin{array}{l}42.6(129) \\
32.8(585) \\
16.6(259)\end{array}$ \\
\hline $\begin{array}{l}\text { Business vs. } \\
\text { State and local } \\
\text { Federal } \\
\text { State and local } \\
\text { vs. federal }\end{array}$ & $\begin{array}{l}58.7(179) \\
25.2(361) \\
37.1(35)\end{array}$ & $\begin{array}{l}42.6(209) \\
27.6(243) \\
\\
46.8(47)\end{array}$ & $\begin{array}{l}47.5(139) \\
31.5(111) \\
\\
22.6(31)\end{array}$ \\
\hline
\end{tabular}

the federal government). Logistic regression is used since the dependent variable for each case is coded 1 if the litigant group won and 0 if it lost. Predictor variables in the four models include the status differential of the litigants (which serves as a proxy for differential resources and litigant experience) ${ }^{8}$ and the aggregate ideological composition of the Court described previously. As a control variable, we also coded whether the litigant group in question was the appellant or respondent in the case.

Confirming the well-established tendency of the Supreme Court to reverse decisions from below, the models in Table 4 clearly indicate that all four classes of litigants have greater probabilities of success when they are appellants. The relationship is statistically significant and strong in all of the models and holds irrespective of the ideological composition of the Court or the relative resources of the litigants.

More important from our perspective, however, is the evidence of the relative effects of litigant resources and the ideology of the Court on the success of litigants. The evidence regarding the former is weak at best. In the business model and state and local government model, resource differentials appear to contribute significantly to the outcome of the case, although the size of the effect is quite modest. Resources, however, are not significant predictors of decisions in cases involving individuals or the federal government.

Further weakening the resource argument is the evidence that the effects of resources in the business model and state and local model stem almost entirely from the tendency of these parties to lose consistently to the federal government. In analyses in which cases involving the federal government are removed (not shown), resources cease to be statistically significant in the business model and are reduced to borderline significance in the state and local government model.

In contrast to resources and experience, the ideology of the Court has had considerable impact on the success rates of litigants of different status. This is most clearly seen for individual litigants who have enjoyed much greater success before the Court during more liberal periods regardless of the resources of opposing litigants or of their status as appellant or respondent.

Predictably, the ideology of the Court also has strong and significant effects on the success of state and local governments. Given that conservatism traditionally accords priority to the claims of order and community over the rights of individuals, it is not surprising that the success of state and local governments before the Court has been related inversely to the liberalism of the Court.

As we have seen, the federal government wins the great majority of its cases against all comers regardless of the relative resources of opposing parties or of the ideology of the Court. Nevertheless, the advantage enjoyed by the federal government in all situations increases significantly as conservatives gain in strength on the Court, although it increases at only about half the rate that the advantage enjoyed by state and local governments does.

\section{TABLE 4}

Logit Estimates for Models of Party Success

\begin{tabular}{|c|c|c|c|c|}
\hline $\begin{array}{l}\text { INDEPENDENT } \\
\text { VARIABLES }\end{array}$ & INDIVIDUAL & BUSINESS & $\begin{array}{l}\text { STATE AND } \\
\text { LOCAL }\end{array}$ & FEDERAL \\
\hline Appellant & $\begin{array}{l}.724^{*} \\
(.079)\end{array}$ & $\begin{array}{l}.903^{\star} \\
(.104)\end{array}$ & $\begin{array}{l}.222^{*} \\
(.087)\end{array}$ & $\begin{array}{l}.897^{*} \\
(.102)\end{array}$ \\
\hline Ideology & $\begin{array}{r}.155^{\star} \\
(.013)\end{array}$ & $\begin{array}{c}-.018 \\
(.032)\end{array}$ & $\begin{array}{r}-.140^{*} \\
(.014)\end{array}$ & $\begin{array}{r}-.079^{\star} \\
(.016)\end{array}$ \\
\hline Resources & $\begin{array}{r}-.094 \\
(.062)\end{array}$ & $\begin{array}{l}.231^{*} \\
(.043)\end{array}$ & $\begin{array}{l}.257^{\star} \\
(.058)\end{array}$ & $\begin{array}{c}-.072 \\
(.083)\end{array}$ \\
\hline $\begin{array}{l}\text { Intercept } \\
\text { Error reduction (\%) }\end{array}$ & $\begin{array}{r}-.843 \\
28\end{array}$ & $\begin{array}{r}-.718 \\
1\end{array}$ & $\begin{array}{r}-.228 \\
17\end{array}$ & $\begin{array}{r}.653 \\
2\end{array}$ \\
\hline
\end{tabular}




\section{TABLE 5}

Time Series Models of the Effects of Ideology on Direct Party Success

\begin{tabular}{|c|c|c|c|c|c|c|}
\hline & \multicolumn{3}{|c|}{ INDIVIDUAL VS. } & \multicolumn{2}{|c|}{ BUSINESS VS. } & \multirow{2}{*}{$\begin{array}{l}\text { STATE VS. } \\
\text { FEDERAL }\end{array}$} \\
\hline & BUSINESS & STATE & FEDERAL & STATE & FEDERAL & \\
\hline Ideology & $\begin{array}{l}2.9 \\
(1.31)\end{array}$ & $\begin{array}{l}3.7 \\
(.973)\end{array}$ & $\begin{array}{l}3.1 \\
(.837)\end{array}$ & $\begin{array}{l}1.1 \\
(.611)\end{array}$ & $\begin{array}{l}-1.3 \\
(.393)\end{array}$ & $\begin{array}{l}2.8 \\
(2.00)\end{array}$ \\
\hline Noise model ${ }^{a}$ & $\begin{array}{c}\mathrm{MA}(3)-.39 \\
(.156)\end{array}$ & $\begin{array}{c}\mathrm{MA}(3)-.29 \\
(.145)\end{array}$ & $\begin{array}{c}\mathrm{MA}(1)-.34 \\
(.094) \\
\mathrm{MA}(5)-.76 \\
(.091)\end{array}$ & - & $\begin{array}{c}\mathrm{MA}(3) .39 \\
(.162)\end{array}$ & 一 \\
\hline $\begin{array}{l}\mathrm{RMS}^{b} \\
\Delta \mathrm{RMS}^{c} \\
\mathrm{Q}^{d}\end{array}$ & $\begin{array}{l}289 \\
14.1 \\
14.0\end{array}$ & $\begin{array}{r}193 \\
18.5 \\
7.1\end{array}$ & $\begin{array}{r}80 \\
35.4 \\
6.8\end{array}$ & $\begin{array}{r}289 \\
18.8 \\
5.4\end{array}$ & $\begin{array}{r}100 \\
25.9 \\
5.8\end{array}$ & $\begin{array}{r}1,239 \\
2.3 \\
12.0\end{array}$ \\
\hline \multicolumn{7}{|c|}{$\begin{array}{l}\text { Note: Models estimated with BMDP2T. Standard errors for parameter estimates in parentheses. Estimates more than twice as large as their standard errors } \\
\text { are significant at the .05 level. } \\
\text { aMoving Average specification for noise; the order of the Moving Average process is in parentheses. } \\
{ }^{b} \text { RMS is the mean of the residual sum of squares for the model; it measures the model's "goodness-of-fit." Lower values indicate a better fit. } \\
{ }^{c} \text { Percentage improvement (i.e. reduction) of the full model compared to the noise model only. } \\
\text { dThe Ljung-Box Q tests of autocorrelation in the model's residuals; with } 12 \text { degrees of freedom, none of the Q estimates are statistically significant at the } \\
.05 \text { level. }\end{array}$} \\
\hline
\end{tabular}

\section{A TIME SERIES PERSPECTIVE}

The evidence so far suggests that the ideological composition of the Supreme Court has a much greater impact on the success of litigants than the resources the litigants possess. To better assess the aggregate effects of the changing ideological character of the Court on litigant success over the past threeand-a-half decades embraced by this analysis, we estimated a series of transfer function models using yearly success rates for each of the six pairs of litigants as dependent variables and the yearly index of the ideological composition of the Court as the independent variable. The transfer function models were estimated using standard Box-Jenkins methods (Box and Jenkins 1976). These enable us to measure the effects that ideology has had on the changing fortunes of the different categories of litigant over the 36-year period, while controlling for the well-known problems associated with time series (Granger and Newbold 1986). ${ }^{9}$

The transfer function models are reported in Table $5 .{ }^{10}$ Since the ideology of each justice is measured on a scale of 1 (most liberal) to -1 (most conservative), the impact coefficients represent, in effect, the average increase in the success rate of one party over another resulting from the replacement of a relatively moderate member of the Court by a liberal member or a conservative member by a moderate one. For example, the coefficient for the impact of ideology on the success rate of individuals involved in litigation against state governments indicates that each unitincrease in the conservatism of the Court has reduced the success rate of individuals against states by slightly less that four percentage points. Although this impact may appear small, its effect over time can be substantial. Thus, from the high-water mark of liberalism on the Court in 1969 (ideology $=6.50$ ) to the high tide of conservatism in 1988 (ideology $=-2.02$ ), the changing ideological composition of the Court was associated with a cumulative reduction in the success rate of individuals of almost 32 percentage points.

The pattern of effects in these models is very similar to that reported in the individual analyses. $\mathrm{New}$ is the evidence of the cumulative magnitude of the effect of the changing ideology of the Court. The impact of ideology on the success rates of individuals is especially dramatic. The increasing conservatism in the Court since the Warren years has been associated with a reduction in the success rates of individuals against business by 25 percentage points, against states by 32 percentage points, and against the federal government by 26 percentage points. As suggested in the analysis of individual cases, the conservative tide has hurt businesses relative to state and local governments. However, the cumulative loss, although statistically significant, has been less than 10 percentage points and has been compensated by an $11 \%$ increase in business successes against the federal government.

The one model in which ideology is not statistically significant involves cases where the federal government opposes local or state governments. Contrary to our expectation that the increasing conservatism on the Court should benefit states in their struggles against the federal government, the direction of the impact coefficient indicates that states have won less frequently against the federal government as the Court has grown more conservative. Although not statistically significant, the size of the coefficient is substantial. One possible explanation for this is simply that the number of cases involving the federal, state, and local governments as opposing litigants is relatively small. Since only slightly more than one hundred such cases have been decided over the 
36-year-period, the success rates for states are highly volatile-especially in the early years, where the number of cases is especially small. Although this would account for the lack of statistical significance, it does not explain the large, contrary-to-theory impact coefficient.

Another possibility is that the impact of ideology on the success of the federal government may depend on the ideological or partisan complexion of the federal government as much as that of the Court. The increasing conservatism of the Supreme Court has not occurred in a vacuum. Rather, it is closely linked to the control of the executive branch of the federal government by conservative Republican administrations. Similarly, the increase in the liberalism of the Court in the 1960s was associated with the domination of that decade by liberal Democratic administrations. Although the ideological complexion of individual state and local governments also changes, the large number of states and localities and the crosscutting nature of change mean that the aggregate ideology of states and localities is much stabler over time than the ideology of the federal government. Given this pattern, it is possible that the ideological orientation of the federal government as a litigant before the Court is linked to the ideology or partisan orientation of the administration and, therefore, that the success of the federal government versus states is a product jointly of the ideology of the Court and of the federal government. In other words, we hypothesize that Democratic administrations will win more frequently against state and local governments as the liberalism of the Court increases but that Republican administrations will win more frequently against states and localities as the Court becomes more conservative.

To test this possibility, we created a partisancontrolled measure of the success of state and local governments versus the federal government and estimated a new transfer function model of the impact of ideology. The results are encouraging. The impact coefficient is strong, negative, and statistically significant, indicating (as predicted) that the success of state and local governments against democratic administrations has declined as the Court has become more liberal and that state successes against Republican administrations have declined as the Court has become more conservative. Although the reduction in the residual mean square produced by this model still is quite small (about 5\%), it is double the reduction achieved in the model without partisan controls.

Finally, the pattern suggested in these data help to explain the observation in Table 3 that the success of state and local governments against the federal government increased in the 1970s before declining in the 1980s. During the early 1970s, Republican administrations faced a still largely liberal Court where, as at the end of the decade, a Democratic administration faced a Court well on its way to becoming conservative. The result was an ideological and partisan environment much more conducive to the interests of states and localities than the 1980s with its conserva- tive Court and Republican administration or the 1960s with a liberal Court and Democratic administrations.

\section{CONCLUSION}

Examination of the success of direct parties before the Supreme Court suggests that litigant resources and experience are considerably less important than in other appellate courts. The contrast between the Supreme Court and the U.S. courts of appeals is especially dramatic. Our analyses confirm the existence of marked differences in the success rates of different categories of litigants before the Supreme Court. However, these differences are not related consistently to litigant status and vary substantially over time in ways suggesting that these differences have little to do with litigant resources or judicial experience and much to do with the changing ideological composition of the Supreme Court.

Moreover, what little evidence there is for the importance of resources and experience stems almost entirely from the observed dominance of the federal government against all other categories of litigants. Although the federal government's consistent success before the Court may be a consequence partly of its superior resources and experience as a repeat player, it also may be due to a variety of other, non-resource-related factors. Among the more important of these, we speculate, is the long-standing substantial evidence doctrine, which encourages judicial deference to the federal government. In addition, our analyses provide evidence of what Dahl (1957) contends is a long-term political dynamic that tends to produce an ideological and partisan "alliance" between members of the Court and presidential administrations. This dynamic is most clearly evident in the increasingly conservative tenor of presidential Court appointments since 1980 and the Court's increasing support for the positions of conservative, Republican administrations during the same period.

Of course, this research can be faulted in a variety of ways. For example, the use of litigants' status as a proxy for their resources and judicial experience introduces considerable measurement error into the analysis, as does the identification of the ideological interests of litigants based on their group identities. As we have noted, even poor defendants with interesting cases can attract skilled and experienced counsel and the financial support of powerful interest groups. Were more direct measures of litigant resources available, we might observe smaller resource differences between litigants and these small differences might have greater effects on judicial outcomes. ${ }^{11}$

Similarly, the diversity of ideological points of view within categories of litigants means that the effects of ideology are almost certainly underestimated. For example, the weak effect that ideology appears to have on the success of state and local governments versus the federal government may result because 
state and local governments frequently press claims (e.g., that their environmental regulations not be overridden by more conservative federal standards) that are more liberal than our underlying assumption recognizes.

Clearly, direct measures of litigant resources and ideological claims would be desirable. Unfortunately they are unavailable. Moreover, such data could not reasonably be obtained for a set of cases as extensive as the Supreme Court data base without a commitment of time and money equal, perhaps, to those already invested in that project.

Nevertheless, although limited by the availability of data and the need to rely on proxies as measures for key concepts, we have provided the first systematic analysis of the success rates of different categories of litigants appearing before the Supreme Court. In addition to demonstrating that success rates of litigants vary widely both across different types of litigants and over time, the analysis is at least suggestive as to the causes of these differences. Theory suggests-and our data support-the argument that litigant success before the Supreme Court depends substantially on the ideological composition of the Court but little, if at all, on the resources and prior judicial experience of the litigants.

\section{Notes}

We wish to thank Harold Spaeth for providing us with a preliminary copy of the U.S. Supreme Court data base, phase

1. The category of poor individuals includes only parties who were clearly identified in the Court opinion as indigent. The individual category is obviously underinclusive, since it excludes individuals who are poor or members of groups usually considered to be protected minorities. It also excludes individuals who appear before the court in their professional capacity. Corporations are defined simply as very large business entities (e.g., airlines, railroads, banks, insurance companies, and oil companies). Small businesses are those which are more likely to have an individual owner-proprietor, including bookstores, realtors, restaurants, and theaters. The residual business category includes businesses in between the other two or whose sizes are ambiguous. A number of parties were not encompassed in any of these categories, including professional associations such as the American Medical Association, churches, clubs, environmental groups, public interest organizations, and nonprofit groups. Since the resource levels or ideological orientations for most of these groups were ambiguous and the number of cases involving a number of these groups were quite small, we have excluded them from the analysis.

2 . The construction of these scores and their underlying assumptions and limitations are discussed in detail by Segal and Cover (1989). Simply, Segal and Cover assign each justice an ideological score between -1 (most conservative) and 1 (most liberal) based on content analyses of newspaper editorial commentaries of the justices' judicial philosophies at the time of their appointments to the Court. The measure was constructed by, in essence, computing the percentage of paragraphs in the editorials of four newspapers that were coded liberal, conservative, or moderate by three separate coders: "Liberal statements include (but are not limited to) those ascribing support for the rights of defendants in criminal cases, women and minorities in equality cases, and the individual against the government in privacy and first amend- ment cases. Conservative statements are those with the opposite direction" (p. 559). The resulting construction reflects the perceived ideology of new justices relative to prevailing values at the time. There were a few early justices who were not included in the Segal and Cover study. We estimated a score for these justices from the scale analyses reported in Rhode and Spaeth 1976 and Schubert 1965. Based on their relative scale scores, the justices were placed within the Segal and Cover scale. Most of these justices were involved in a small number of cases. The two who were involved in a large number of cases were Black and Douglas, both of whom it was very easy to classify as liberals.

3. During the period under study, the Court's reversal rate was $67 \%$.

4. This measure reverses the logic advanced by Wheeler and his colleagues in measuring the effects of the opposite tendency of state courts to affirm cases from below $(1987,418)$.

5 . Because the number of cases for several categories of litigants becomes very small when disaggregated over time, we collapsed the 10 categories of litigants used in other analyses into four categories: individuals, businesses, state and local governments, and the federal government. Since unions do not fit naturally into any of these categories and were involved in relatively few cases, we dropped them from the remainder of the analysis.

6. These periods were chosen primarily on the basis of political factors surrounding the appointment of new justices and the effect of these appointments on decisional trends. The 1953-70 period corresponds with the appointment of Chief Justice Warren up to the appointment of Justice Blackmun. After the appointment of Blackmun in the early Burger Court, we see a significant change in the number of liberal decisions emanating from the Court. During the period 1981-88, we see an even greater drop in the number of liberal decisions delivered by the Court. These three periods allow us to obtain an indication of the effect of changes in the Court's composition and ideological direction, on the success of different types of parties.

7. It could be argued that the individual success rates are the result of the low success rates that criminal defendants generally have in appellate courts. To control for this possibility, the success rates of individuals were analyzed for criminal and noncriminal cases. Utilizing the same court periods, the success of individuals in criminal cases were $58.1 \%$ (Court 1), $31.8 \%$ (Court 2), and $25.1 \%$ (Court 3). In civil cases, individual success rates were $61.1 \%, 41.7 \%$, and $30.1 \%$, respectively. Thus, we conclude that the success of individuals has consistently declined across time in both criminal and noncriminal cases, and these data provide further evidence of the impact of ideological change on the fate of individual litigants.

8. The status/resource variable assumes a status continuum along which individuals $=1$, business $=2$, state and local governments $=3$, and federal government $=4$. Thus, when a case involves the federal government versus individuals as litigants, the status/resource differential is 3 or -3 , depending on whether the model is explaining federal success or individual success. Similarly, when an individual opposes a business, the business would be coded as having a status/resources advantage of 1 if the individual was coded as having a disadvantage of -1 .

9. The use of Box-Jenkins procedures also makes it possible to test for Granger causality in the relationship between the Court's ideology and litigant success rates (Freeman 1983; Granger 1969). Strictly speaking, Granger causality implies that lagged values of $X$ explain variance in current values of $Y$ that cannot be explained by past values of $Y$. In this case, it means that past values of the Court's ideology explain current litigant success that cannot be explained by past values of litigant success. (E.g., the introduction of lagged values for ideology result in a significant improvement in the residual mean square.) In fact, the best-fitting model specifications for all litigant groups is a model in which the effects of ideology on success rates are unlagged. In every case, a model specified with a lagged ideology effect of one year was also 
significant, albeit somewhat smaller. Although the specification of unlagged ideology effects weakens the case for Granger causality in these relationships, the significant improvement in the residual mean square registered in all of the models except the state-and-local-versus-federal-government one provides at least modest evidence of Granger causality.

10. The impact coefficients in these models measure the expected change in the success rates of an opposing pair of litigants produced by a one-unit change in the aggregate ideology of the Court. Several of the models have significant moving average components in the error term. These indicate the existence of short stochastic cycles. The statistics at the bottom of the table provide summary measures of the models' performance and indicate that all of the models perform acceptably (again, except for the federal-versus-state-andlocal model). Ideology produces reductions in the residual mean square in each model of between $15 \%$ and $35 \%$, and the Ljung-Box Q-statistic indicates that the residuals in all models are appropriately free of autocorrelation.

11. It should be noted, however, that our measure of litigant status/resources is the same used in previous studies where resources have been shown to be significantly related to judicial success rates (Sheehan and Songer 1989). Thus, the suggestion that resource differentials are smaller and less consistent among Supreme Court litigants and have smaller effects on litigant success is less a problem of measurement than confirmation of our initial hypothesis about the limited impact of resources on Supreme Court outcomes.

\section{References}

Box, George E., and Gwilyn M. Jenkins. 1976. Time Series Analysis: Forecasting and Control. Rev. ed. San Francisco: Holden-Day.
Dahl, Robert. 1957. "Decision-Making in a Democracy: The Supreme Court as a National Policymaker." Journal of Public Law 6:279-95.

$\rightarrow$ Freeman, John R. 1983. "Granger Causality and Time Series Analysis of Political Relationships." American Journal of Political Science 27:327-58.

$\rightarrow$ Galanter, Marc. 1974. "Why the 'Haves' Come Out Ahead: Speculations on the Limits of Social Change." Law and Society Review 9:95-160.

$\rightarrow$ Granger, Clive William John. 1969. "Investigating Causal Relations by Econometric Models and Cross Spectral Methods." Econometrica 37:424-38.

Granger, Clive William John, and Paul Newbold. 1986. Forecasting Economic Time Series. San Diego: Academic.

Rohde, David, and Harold Spaeth. 1976. Supreme Court Decisionmaking. San Francisco: Freeman.

Schubert, Glendon. 1965. The Judicial Mind. Evanston, IL: Northwestern University Press.

$\rightarrow$ Segal, Jeffrey A., and Albert Cover. 1989. "Ideological Values and the Votes of U.S. Supreme Court Justices." American Political Science Review 83:557-65.

Sheehan, Reginald S., and Donald R. Songer. 1989. "Parties before the United States Courts of Appeals in the 1980s." Paper presented at the annual meeting of the Midwest Political Science Association.

$\rightarrow$ Tate, C. Neal. 1981. "Personal Attribute Models of Voting Behavior of U.S. Supreme Court Justices: Liberalism in Civil Liberties and Economics Decisions, 1946-1978." American Political Science Review 75:355-67.

$\rightarrow$ Wheeler, Stanton, Bliss Cartwright, Robert Kagan, and Lawrence Friedman. 1987. "Do the 'Haves' Come Out Ahead? Winning and Losing in State Supreme Courts, 1870-1970." Law and Society Review 21:403-45.

Reginald S. Sheehan is Assistant Professor of Political Science, University of North Texas, Denton, TX 76203-5338.

William Mishler is Professor and Donald R. Songer is Associate Professor of Government and International Studies, University of South Carolina, Columbia, SC 29208 